\title{
Taxonomic note: necessary correction of specific and subspecific epithets according to Rules 12c and 13b of the International Code of Nomenclature of Bacteria (1990 Revision)
}

\author{
J. P. Euzéby \\ Fax: +33561 1939 75. e-mail: j.euzeby@envt.fr
}

Laboratoire de Bactériologie, École Nationale Vétérinaire, 23 Chemin des Capelles, F-31076 Toulouse cedex 3, France

\author{
Specific epithets and subspecific epithets treated as adjectives must agree in \\ gender with the generic names (Rules $12 \mathrm{c}$ and $13 \mathrm{~b}$ of the International Code of \\ Nomenclature of Bacteria). Thirty-four cases that do not respect theses Rules \\ are corrected.
}

Keywords: nomenclatural changes, epithet, adjective, gender, International Code of Nomenclature of Bacteria
Latin is the only language permitted for the classification of living organisms and, in microbiology, Latin designations have been used from the beginning (MacAdoo, 1993). Not all bacteriologists are Latin scholars and, in spite of the guidelines provided by the International Code of Nomenclature of Bacteria (Lapage et al., 1992), Buchanan (1957, 1994), MacAdoo (1993) and Trüper (1996), numerous mistakes have been made in naming species and genera of prokaryotes.

Changes in the spelling of bacterial names irritate a lot of bacteriologists who think that there are more important things to do in science than this hairsplitting business. On the other hand, Rule 57a states that 'Any name or epithet should be written in conformity with the spelling of the word from which it is derived and in strict accordance with the rules of Latin and latinization', and according to Rule 3, 'Names contrary to a Rule cannot be maintained, ...'

Among the more serious mistakes that cannot be allowed in Latin are adjectives modifying a noun but that do not agree in gender with this noun. Rules $12 \mathrm{c}$ and $13 \mathrm{~b}$ therefore state that specific epithets and subspecific epithets that are adjectives must agree in gender with the generic names.

I recently proposed (Euzéby, 1998) an emendation of the note of Rule 61 to avoid changes in the spelling of names included in the Approved Lists of Bacterial Names (Skerman et al., 1980), and I shall not propose corrections for such epithets even if they are in violation of Rules $12 \mathrm{c}$ and $13 \mathrm{~b}$. On the contrary, the following names should be changed.

References for effective and valid publications of the names cited below can be found in the List of Bacterial Names with Standing in Nomenclature http:// www-sv.cict.fr/bacterio/ (Euzéby, 1997).

Epithets that do not agree with generic names assigned to the masculine gender

Bacteroides tectum should be changed to Bacteroides tectus (L. part. masc. adj. tectus concealed).

Haloincola saccharolytica, Haloincola saccharolytica subsp. saccharolytica and Haloincola saccharolytica subsp. senegalensis should be changed to Haloincola saccharolyticus (Gr. n. sacchar sugar; Gr. adj. lytos loosening, dissolving; M.L. adj. lyticus, -a, -um dissolving; M.L. masc. adj. saccharolyticus sugardissolving), Haloincola saccharolyticus subsp. saccharolyticus and Haloincola saccharolyticus subsp. senegalensis, respectively.

Methanoculleus bourgense should be changed to Methanoculleus bourgensis (Bourg-en-Bresse, name of a locality; L. suff. -ensis, $-i s$, -e relating to; M.L. masc. adj. bourgensis referring to Bourg-en-Bresse).

Nocardioides fastidiosa should be corrected to Nocardioides fastidiosus (L. masc. adj. fastidiosus fastidious).

Paenibacillus durum should be changed to Paenibacillus durus (M.L. masc. adj. durus hard, tough, resistant).

Streptococcus difficile should be changed to Streptococcus difficilis (L. masc. adj. difficilis difficult). However, Vandamme et al. (1997) recently demonstrated that Streptococcus difficile Eldar et al. 1995 is a variant of Streptococcus agalactiae Lehmann and Neumann 
1896 (Approved Lists 1980) and that this name is illegitimate (but it is not placed on the list of rejected names).

Streptomyces viridoflavum should be changed to Streptomyces viridiflavus (L. adj. viridis, $-i s,-e$ green; preferred connecting vowel $-i-;$ L. adj. flavus, - a, -um yellow; M.L. masc. adj. viridiflavus green-yellow).

\section{Epithets that do not agree with generic names assigned to the feminine gender}

Colwellia psychroerythrus should be changed to Colwellia psychrerythraea [Gr. adj. psychros cold; no extra connecting vowel is required; L. adj. erythraeus, - $a$, -um red; M.L. fem. adj. psychrerythraea cold (adapted) and red].

Erwinia persicinus should be changed to Erwinia persicina (M.L. fem. adj. persicina peach-coloured).

Gordonia rubropertinctus should be corrected to Gordonia rubripertincta (L. adj. ruber bra brum red; preferred connecting vowel $-i-$; L. pref. per very; $\mathbf{L}$. part. adj. tinctus, $-a$, -um dyed; M.L. fem. adj. rubripertincta heavily dyed red).

Halomonas pantelleriense should be changed to Halomonas pantelleriensis (Pantelleria island, name of a locality; the vowel $a$ should be dropped; L. suff. ensis, $-i s$, $-e$ relating to; M.L. fem. adj. pantelleriensis referring to Pantelleria island).

Megamonas hypermegas should be changed to Megamonas hypermegale (Gr. pref. hyper over, more than; Gr. adj. megas, megale, mega big; M.L. fem. adj. hypermegale very big). As MacAdoo (1993) says, the Greek adjectives are so complicated that one needs to be an expert in both languages to put the Greek properly into Latin form. However, Pline (Plinius Secundus), in Naturalis historia, uses the feminine adjective megale (Gaffiot, 1934).

Mitsuokella multiacidus should be changed to Mitsuokella multacida (L. adj. multus, -a, -um many; no connecting vowel is required; $\mathrm{L}$. adj. acidus, $-a$, -um sour; M.L. fem. adj. multacida producing much acid).

Saccharothrix aerocolonigenes subsp. staurosporeus should be changed to Saccharothrix aerocolonigenes subsp. staurosporea (Gr. n. stauros stave; Gr. n. spora a spore; M.L. fem. adj. staurosporea referring to a slender spore).

Tsukamurella paurometabolum should be Tsukamurella paurometabola (Gr. adj. paurus little; Gr. adj. metabolus changeable; M.L. fem. adj. paurometabola little changeable, probably meaning 'producing little change').

\section{Epithets that do not agree with generic names assigned to the neuter gender}

Acetomicrobium faecalis should be corrected to Acetomicrobium faecale (M.L. neut. adj. faecale pertaining to faeces).
Acidiphilium aminolytica should be changed to Acidiphilium aminilyticum (M.L. n. aminum amine; preferred connecting vowel $-i-; \mathrm{Gr}$. adj. lytos loosening, dissolving; M.L. adj. lyticus, - a, -um dissolving; M.L. neut. adj. aminilyticum amine-dissolving).

Acidiphilium facilis should be changed to Acidiphilium facile (L. neut. adj. facile easy).

Clostridium fervidus should be Clostridium fervidum (L. neut. adj. fervidum boiling).

Clostridium intestinalis should be changed to Clostridium intestinale (M.L. neut. adj. intestinale pertaining to the intestine).

Corynebacterium variabilis should be Corynebacterium variabile (L. neut. adj. variabile changeable, variable).

Cyclobacterium marinus should be corrected to Cyclobacterium marinum (L. neut. adj. marinum of the sea, marine).

Desulfomicrobium baculatus should be changed to Desulfomicrobium baculatum (M.L. neut. adj. baculatum rod-shaped).

Dictyoglomus turgidus should be changed to Dictyoglomus turgidum (L. neut. adj. turgidum swollen). The original authors failed to indicate the gender of the genus Dictyoglomus. However, according to Rule 65(2), the genus Dictyoglomus is of neuter gender (L. neut. n. glomus ball).

Hyphomicrobium facilis, Hyphomicrobium facilis subsp. facilis, Hyphomicrobium facilis subsp. tolerans and Hyphomicrobium facilis subsp. ureaphilum should be changed to Hyphomicrobium facile (L. neut. adj. facile easy), Hyphomicrobium facile subsp. facile, Hyphomicrobium facile subsp. tolerans and Hyphomicrobium facile subsp. ureaphilum, respectively.

Methanohalobium evestigatus should be changed to Methanohalobium evestigatum (L. neut. adj. evestigatum discovered).

Sinorhizobium xinjiangensis should be corrected to Sinorhizobium xinjiangense (Xinjiang, name of a locality; L. suff. -ensis, -is, -e relating to; M.L. neut. adj. xinjiangense referring to Xinjiang).

Sphingobacterium antarcticus should be changed to Sphingobacterium antarcticum (M.L. neut. adj. antarcticum pertaining to the Antarctic).

To avoid further mistakes in the future, authors are recommended to consult a classicist before proposing new names for bacteria.

\section{References}

Buchanan, R. E. (1957). How bacteria are named and identified. In Bergey's Manual of Determinative Bacteriology, 7th edn, pp. 15-28. Edited by R. S. Breed, E. G. D. Murray \& N. R. Smith. Baltimore: Williams \& Wilkins.

Buchanan, R. E. (1994). Taxonomic notes: an aid to formation of bacterial names. Chemical terminology and microbiological nomenclature. Int J Syst Bacteriol 44, 588-590. 
Euzéby, J. P. (1997). List of bacterial names with standing in nomenclature: a folder available on the Internet. Int $J$ Syst Bacteriol 47, 590-592.

Euzéby, J. P. (1998). Proposal to amend the Rule 61 of the International Code of Nomenclature of Bacteria (1990 revision). Int J Syst Bacteriol 48, 611-612.

Gaffiot, F. (1934). Dictionnaire Latin Français. Paris: Hachette. Lapage, S. P., Sneath, P. H. A., Lessel, E. F., Skerman, V. B. D., Seeliger, H. P. R. \& Clark, W. A. editors (1992). International Code of Nomenclature of Bacteria (1990 Revision). Washington, DC: American Society for Microbiology.

MacAdoo, T. O. (1993). Nomenclatural literacy. In Handbook of
New Bacterial Systematics, pp. 339-358. Edited by $\mathbf{M}$. Goodfellow \& A. G. O'Donnell. London: Academic Press.

Skerman, V. B. D., McGowan, V. \& Sneath, P. H. A. (editors) (1980). Approved lists of bacterial names. Int J Syst Bacteriol 30, 225-420.

Truper, H. G. (1996). Help! Latin! How to avoid the most common mistakes while giving Latin names to newly discovered prokaryotes. Microbiología (Sociedad Española de Microbiología) 12, 473-475.

Vandamme, P., Devriese, L. A., Pot, B., Kersters, K. \& Melin, P. (1997). Streptococcus difficile is a nonhemolytic group B, type Ib streptococcus. Int J Syst Bacteriol 47, 81-85. 